\title{
SANITASI ALERGEN PADA PROSES PRODUKSI BISKUIT DALAM UPAYA MENGURANGI RESIDU ALERGEN TELUR
}

\author{
[Allergen Sanitation in Biscuit Production Process to Reduce Egg Allergen Residu]
}

\author{
Kartika Sari ${ }^{1)}$, Nurheni Sri Palupi ${ }^{2,3) \star}$, dan Puspo Edi Giriwono ${ }^{2,3)}$ \\ 1) Program Studi Magister Teknologi Pangan, Sekolah Pascasarjana, IPB University, Bogor \\ 2) Departemen IImu dan Teknologi Pangan, Fakultas Teknologi Pertanian, IPB University, Bogor \\ ${ }^{3)}$ South East Asian Food and Agricultural Science and Technology (SEAFAST) Center, IPB University, Bogor
}

Diterima 15 Desember 2020 / Disetujui 10 November 2021

\begin{abstract}
Food allergy is a hypersensitive response to food, generally protein, triggered by body immune system. These responses can be mild, however in very rare cases may cause severe reactions and life threatening known as called anaphylaxis. Food allergy has been one of the main factors for product recall. It can happen due to many reasons, such as product package labeling fault, raw material labeling fault and cross contamination. Validation of the effectiveness of cleaning and sanitation process become a critical point to minimize cross contamination. This study aimed to determine the optimum chemical concentration and contact time to eliminate egg residue in biscuit production cleaning process, obtain valid and verified cleaning procedures, and produce cleaning procedures that can be implemented in a production line. The result showed that physical cleaning/pre-cleaning for 30 minute and using $1 \%(\mathrm{v} / \mathrm{v})$ concentration of caustic based polybrite chemical cleaning for 3-minute contact time can effectively eliminate the egg residue on stainless steel and polyurethane surface equipment. Food contact surface material and product characteristics (wet dough, dry biscuit) affected the number of egg residue on the equipment. Packing area with food contact surface equipment made from stainless steel is not considered critical area for allergen sanitation. It is shown that prior to sanitation process, analysis of egg allergen residue has already given negative result. Validation process can prove the effectiveness of allergen sanitation process to prevent potential egg allergen cross contamination in biscuit production.
\end{abstract}

Keywords: biscuit, egg allergen residue, sanitation, validation method

\begin{abstract}
ABSTRAK
Alergi pangan merupakan respon abnormal terhadap pangan (umumnya protein) yang dipicu oleh sistem kekebalan tubuh. Respon ini dapat bersifat ringan atau dalam kasus yang jarang terjadi dapat bersifat berat dan bahkan mengancam jiwa yang disebut anafilaksis. Alergi pangan masih merupakan salah satu faktor tertinggi dalam kasus penarikan produk dari peredaran. Penyebab penarikan produk akibat isu alergen bermacam-macam diantaranya adalah kesalahan label kemasan produk, kesalahan label bahan baku dan kontaminasi silang. Validasi terhadap efektivitas proses pembersihan dan sanitasi peralatan industri merupakan hal yang kritikal dalam menghindari risiko kontaminasi silang. Penelitian ini bertujuan untuk mendapatkan konsentrasi bahan kimia dan waktu kontak optimum untuk pembersihan residu alergen telur, memperoleh prosedur pembersihan pada peralatan produksi yang valid dan terverifikasi, serta mendapatkan prosedur pembersihan yang dapat diimplementasikan pada lini produksi. Hasil penelitian menunjukkan bahwa penggunaan perlakuan pembersihan fisikal/pre-cleaning selama 30 menit, konsentrasi bahan kimia pembersih polybrite $1 \%(\mathrm{v} / \mathrm{v})$ dan waktu kontak 3 menit dalam proses sanitasi terbukti efektif dalam menghilangkan residu alergen telur pada material stainless steel dan polyurethane dalam proses produksi biskuit. Tipe material dan pengotor berpengaruh dalam jumlah residu telur yang menempel pada peralatan proses produksi. Area pengemasan (packing) dengan peralatan berbahan stainless steel dan pengotor tipe kering (remahan produk jadi) tidak menunjukkan adanya residu alergen telur sebelum proses sanitasi alergen (residu alergen negatif), sehingga area ini dapat dianggap sebagai area yang tidak kritis dalam proses sanitasi alergen. Proses validasi yang dilakukan dapat menunjukkan efektivitas proses sanitasi alergen yang dilakukan untuk mengatasi kemungkinan terjadinya kontaminasi silang alergen telur dalam produksi biskuit.
\end{abstract}

Kata Kunci: biskuit, residu alergen telur, sanitasi, validasi metode

*Penulis Korespondensi: E-mail: hnpalupi@apps.ipb.ac.id 


\section{PENDAHULUAN}

Alergi pangan merupakan salah satu isu kesehatan yang penting saat ini. Menurut Sicherer (2011) alergi pangan berdampak terhadap kurang lebih $2 \%$ orang dewasa dan $8 \%$ anak-anak di Amerika Serikat serta jumlah ini selalu meningkat setiap tahunnya (Loh et al., 2018). Sebagian besar reaksi alergi yang terjadi merupakan reaksi alergi yang ringan (gatal-gatal), beberapa alergi pangan dapat menjadi masalah kesehatan yang serius (rhinorrhea, eksim, urticaria, asma) dan tidak jarang dapat membahayakan jiwa (reaksi anafilaksis) (Żukiewicz-Sobczak et al., 2013). Tidak ada obat untuk alergi, sehingga upaya yang dapat dilakukan untuk mencegah terjadinya reaksi alergi antara lain yaitu menghindari makanan yang menyebabkan alergi, pengenalan dini dan manajemen terhadap reaksi alergi. Banyak jenis bahan pangan dapat menyebabkan alergi, tetapi $90 \%$ alergi disebabkan oleh susu sapi, kedelai, telur, gluten, kacang tanah, ikan, dan krustacea (termasuk udang, rajungan, dan kepiting) (FDA, 2016).

Alergi pangan dapat berdampak fatal bagi kesehatan manusia, sehingga perlu mendapat perhatian yang sangat penting. Codex Alimentarius Commission (CAC) merekomendasikan agar informasi mengenai alergen harus dituliskan pada label produk pangan. Di Amerika Serikat, peraturan terkait pelabelan produk pangan dan perlindungan konsumen (FALCPA-Food Allergen Labeling and Consumer Protection Act) mempersyaratkan bahwa semua produk pangan dalam kemasan yang dijual di Amerika wajib mencantumkan bahan pangan pemicu alergi (susu, telur, kacang tanah, tree nuts, gandum, kedelai, ikan, kerang) ketika bahan tersebut ditambahkan dengan sengaja ke produk pangan (FDA, 2016). Hal ini sejalan dengan peraturan yang sama juga ditetapkan di negara-negara Uni Eropa. Di Indonesia, peraturan mengenai alergen pangan dikeluarkan oleh BPOM di tahun 2018, melalui Peraturan Kepala BPOM No. 31 tahun 2018 pasal 49 dan pasal 50 mengenai Label Pangan Olahan. Peraturan tersebut mewajibkan pelaku usaha dan produsen pangan untuk memastikan bahwa bahan pangan utama penyebab utama alergi wajib dicantumkan dalam label dengan benar dan akurat.

Industri pembuatan biskuit umumnya memiliki berbagai ragam formulasi produk, baik yang menggunakan bahan pangan alergen (pemicu alergi) seperti telur, susu dan terigu maupun bahan pangan lainnya (gula, minyak maupun lemak nabati, garam, pengembang, dan lain lain). Telur merupakan bahan baku penting dalam proses produksi biskuit, akan tetapi banyak variasi produk biskuit dibuat tidak menggunakan telur. Berdasarkan Lee et al. (2013) telur merupakan bahan pemicu alergen utama di sebagian besar negara Asia (khususnya Cina, Korea dan sebagian negara Asia Tenggara), reaksi alergi ini terutama terjadi di anak-anak usia 1-5 tahun. Penelitian Samady et al. (2020) terhadap tingkat prevalensi alergi di Amerika Serikat memperkirakan bahwa alergi telur terdapat pada $0,9 \%$ anak-anak dan $1,3 \%$ anak-anak dibawah 5 tahun. Reaksi alergi yang terjadi akibat alergi telur biasanya adalah peradangan atau ruam pada kulit. Gangguan pernafasan dan pencernaan juga merupakan hal yang mungkin terjadi. Tingkat keparahan terhadap reaksi alergi sangat sulit diprediksi serta dapat berakibat fatal. Reaksi anafilaksis dilaporkan juga dapat terjadi terkait alergi telur (Caubet dan Wang, 2011). Manajemen pengelolaan alergen khususnya telur menjadi hal yang sangat penting pada industri biskuit.

Sejak awal tahun 1990, industri pangan mulai mendedikasikan sumber daya dalam mengembangkan rencana pengendalian alergen pangan, dengan tujuan untuk mencegah adanya alergen yang tidak diinginkan di produk pangan (Taylor dan Hefle, 2005). Walaupun peraturan mengenai pelabelan produk alergen sudah sangat ketat, namun penarikan produk dikarenakan alergi pangan masih menduduki peringkat tertinggi dalam beberapa tahun terakhir (Gendel dan Zhu, 2013; Gendel et al., 2014). Kategori pangan yang memiliki angka penarikan produk pangan tertinggi diantara adalah produk bakeri, produk permen dan sejenisnya dan produk susu serta turunannya (Gendel et al., 2014). Kesalahan label pangan merupakan penyebab terbesar dari penarikan produk pangan terkait alergen pangan, akan tetapi kontaminasi silang berkontribusi signifikan sebesar $11 \%$ dari total penarikan produk dari pasar (Gendel dan Zhu, 2013). Penelitian terbaru oleh Soon et al. (2020) menyebutkan bahwa bahan pangan alergen yang tidak dinyatakan dalam label merupakan kasus tertinggi $(40,45 \%)$ penyebab penarikan produk pangan dari pasar. Kontaminasi silang terjadi ketika residu dari sejumlah kecil dari bahan pangan yang mengandung alergen secara tidak sengaja terbawa atau bersinggungan dengan bahan pangan lain yang non-alergen dalam rantai proses pembuatan produk. Hal yang umum menjadi penyebab kontaminasi silang adalah penggunaan bersama peralatan proses antara bahan pangan alergen dan bahan pangan bukan alergen, serta proses sanitasi yang kurang efektif (Bedford et al., 2017). Berdasarkan Ryther (2014) penggunaan bahan kimia mempermudah proses pelarutan kotoran dari bahan pangan sehingga proses pembersihan dengan bahan kimia pembersih dapat dengan efektif mengurangi dan bahkan menghilangkan bahan pangan dari permukaan peralatan yang digunakan dalam memproses bahan pangan selama proses sanitasi. Bahan pangan dapat terdiri dari bermacam macam komponen seperti tepung, minyak, protein dan lainnya. Pemilihan bahan kimia yang tepat sangat penting untuk dapat memastikan 
bahan pangan yang ingin dihilangkan seperti alergen pangan dapat dengan tepat hilang dan tidak meninggalkan residu di permukaan peralatan.

Berbagai langkah pengendalian alergen diterapkan seperti segregasi produk alergen dan nonalergen, program pengendalian bahan semenjak dari pemasok, pencegahan kontaminasi silang, pengaturan jadwal produksi dan penggunaan rework, pelabelan dan penerapan program sanitasi alergen yang tervalidasi (Jackson et al., 2008; Cochrane dan Skrypec, 2014). Umumnya proses penghilangan atau penurunan residu alergen dilakukan pada permukaan yang bersentuhan dengan bahan pangan. Proses tersebut biasanya dilakukan dengan pencucian dan melakukan sanitasi menggunakan bahan kimia pembersih (Jackson et al., 2008). Menurut Stein (2015), proses sanitasi merupakan elemen yang penting dalam mencegah kontaminasi silang. Proses pembersihan dan sanitasi yang tepat dan efektif dapat membantu industri pangan untuk memastikan tidak adanya risiko kontaminasi silang dari bahan pangan alergen ke bahan pangan bukan alergen dan membantu industri untuk merencanakan proses produksinya dengan seefektif mungkin. Penelitian ini bertujuan untuk menentukan efektivitas sanitasi alergen di industri pangan, khususnya dalam upaya mengurangi residu alergen telur pada proses industri biskuit. Waktu pembersihan manual, tipe pengotor dan tipe material pembuat peralatan proses juga merupakan faktor yang diamati pengaruhnya dalam penurunan residu alergen telur selama proses sanitasi alergen.

\section{BAHAN DAN METODE}

\section{Bahan}

Bahan yang digunakan dalam penelitian ini adalah adonan biskuit kukis yang mengandung bahan baku tepung telur $0,2 \%$, bahan kimia pembersih merk Poly-brite (Ecolab, Jerman) dan produk kukis yang dihasilkan dalam proses produksi (mengandung 2000 ppm tepung telur). Analisis dilakukan menggunakan 2 metode, yaitu dengan metode deteksi Adenosin Tri Phosphate (ATP) menggunakan $3 \mathrm{M}$ Clean Trace ${ }^{T M}$ Luminometer dan 3M Clean Trace $^{T M}$ Surface ATP Test Swab UXL 100 (3M, United Kingdom) dan metode deteksi Lateral Flow Device (LFD) menggunakan alergen test kit lateral flow device (Romer Agrastrip®Egg, Austria). Produk biskuit hasil produksi setelah proses sanitasi alergen diuji di laboratorium PT. SGS Indonesia dengan menggunakan metode Enzyme-Linked Immunosorbent Assays (ELISA).

\section{Penentuan konsentrasi bahan kimia pembersih dan waktu kontak proses sanitasi alergen (Ryther, 2014; Holah, 2014)}

Hasil diskusi dengan rekanan bahan kimia pembersih $\mathrm{PT}$. XYZ, disarankan penggunaan bahan kimia pembersih polybrite dari Ecolab yang merupakan bahan kimia pembersih dengan bahan aktif sodium (alkali). Menurut Holah (2014), mekanisme dari proses pembersihan dan sanitasi dipengaruhi oleh 4 faktor utama yaitu waktu, pembersihan fisik, konsentrasi bahan kimia dan temperatur. Penggunaan bahan kimia pembersih dilakukan untuk mempermudah pembersihan kotoran dengan cara memecah komponen kimia pada pengotor, sehingga kotoran akan mudah diangkat dari permukaan alat. Penentuan kadar konsentrasi bahan kimia pembersih polybrite dan waktu kontak yang digunakan diperoleh dari technical data sheet polybrite yang menjelaskan rentang konsentrasi bahan kimia yang dapat diaplikasikan dalam proses sanitasi di industri pangan. Perlakuan dari penelitian ini adalah hasil kombinasi antara faktor konsentrasi bahan kimia pembersih polybrite dan waktu kontak. Faktor pertama adalah konsentrasi bahan kimia pembersih polybrite, yaitu A1 (1\%), A2 (2\%) dan A3 (3\%). Faktor kedua adalah waktu kontak bahan kimia pembersih polybrite dengan lempengan material berbahan stainless steel dan polyurethane yaitu, B1 (3 menit), B2 (5 menit) dan B3 (8 menit), sehingga terdapat 9 kombinasi yang akan dianalisis, yaitu A1B1, A1B2, A1B3, A2B1, A2B2, A2B3, A3B1, A3B2 dan A3B3 dengan 2 kali ulangan.

Pengujian di laboratorium dilakukan dengan 2 metode pembersihan yaitu pembersihan basah (wet cleaning) untuk material berbahan stainless steel dan pembersihan basah terkontrol (controlled wet cleaning) untuk material berbahan polyurethane yang diperoleh dari pemasok konveyor (Yongli, Cina). Kedua metode pembersihan ini prisipnya sama, yaitu menggunakan air. Pemilihan tipe material dan metode pembersihan dilakukan berdasarkan tipe material yang umum digunakan sebagai bahan pembuat peralatan produksi di industri pangan. Pengotoran permukaan alat dilakukan dengan menggunakan bahan adonan kukis yang diambil dari proses produksi. Kemudian dilakukan proses sanitasi dengan perlakuan pembersikan fisikal/precleaning dengan cara pengerokan dan pengelapan pada permukaan lempengan alat dan dilanjukan dengan pembersihan menggunakan kombinasi kedua faktor perlakuan (konsentrasi bahan kimia pembersih dan waktu kontak). Setelah proses sanitasi selesai, dilakukan pengujian dengan menggunakan metode deteksi ATP (3M Clean Trace ${ }^{\text {TM }}$ Surface ATP, United Kingdom) sebagai indikator umum hasil sanitasi dan metode deteksi LFD (Romer Agrastrip $\mathbb{B}$ Egg, Austria) untuk pengujian residu alergen telur. 
Pengujian di laboratorium dilakukan untuk mendapatkan konsentrasi bahan kimia pembersih dan lama waktu kontak yang optimum dalam menghilangkan residu alergen telur. Hasil optimum yang dipilih merupakan hasil negatif (LOD $0,2 \mu \mathrm{g} / 25 \mathrm{~cm}^{2}$. swab tes) dari pengujian residu telur menggunakan test kit lateral flow device dengan kombinasi konsentrasi bahan kimia terendah dan waktu kontak terpendek.

Mengacu pada proses cleaning peralatan kantin sekolah, maka evaluasi keberadaan alergen (susu, telur dan gluten) pada peralatan kontak pangan dalam upaya memverifikasi efektivitas penurunan residu alergen dilakukan dengan dua acara. Salah satunya adalah menggunakan metode deteksi cepat kualitatif LFIA (Lateral-Flow Immuno Assay)/ LFD yaitu, test yang dapat digunakan langsung di tempat. Metode lainnya adalah pengecekan spesifik alergen pangan menggunakan metode ELISA (Ortiz et al., 2018; Galan-Malo et al., 2019). Pada penelitian ini, pengujian menggunakan metode deteksi ATP dilaksanakan sebagai indikator umum kebersihan dari peralatan setelah dilakukan proses sanitasi alergen. Metode ini memberikan hasil yang cepat dengan proses yang mudah untuk memberikan gambaran proses sanitasi yang dilakukan sudah berjalan baik dan maksimal sebelum kemudian dilakukan proses pengujian alergen telur menggunakan metode deteksi LFD.

\section{Metode deteksi ATP (AOAC, 2019)}

Penggunaan alat pengukur ATP, yang disebut sebagai luminometers (3M Clean Trace ${ }^{\mathrm{TM}}$ Surface ATP, United Kingdom) didasarkan pada reaksi yang terjadi antara ATP dan bahan kimia luciferase yang dapat memproduksi cahaya. Cahaya yang keluar diukur dengan alat (dalam lumens) mengindikasikan level dari ATP yang ada. Alat ini juga dapat mengindikasikan adanya mikroorganisme, karena bakteri merupakan organisme hidup yang memiliki level ATP, sehingga alat ini dapat membaca ATP yang ada pada bakteri, juga pada bahan organik seperti protein, lemak, dan lainnya atau kombinasi keduanya (Jarrad, 2019). Pada penelitian ini, pengujian untuk mengetahui tingkat kebersihan atau sanitasi dari peralatan yang telah disanitasi dilakukan dengan metode swab menggunakan $3 \mathrm{M}$ Clean Trace $^{T M}$ Surface ATP Test Swab UXL 100 terhadap permukaan peralatan dan dilakukan pengukuran menggunakan $3 \mathrm{M}$ Clean Trace ${ }^{T M}$ Luminometer dengan cara memasukan kapas usap ke dalam perangkat 3M Clean Trace ${ }^{T M}$ Luminometer, alat kemudian diaktivasi dengan cara menekan bagian atas alat, sehingga dakron bereaksi dengan cairan luciferin/luciferase, proses ditunggu selama 3-5 detik untuk mendapatkan homogenasi dan dilakukan pembacaan pada alat ATP. Jumlah senyawa ATP muncul pada layar alat pembaca dalam satuan rela- tive light unit (RLU). Luas permukaan swab mengikuti prosedur penggunaan dari 3M Clean Trace ${ }^{T M}$ Hygiene Monitoring and Management System, yaitu $10 \times 10 \mathrm{~cm}$ pada permukaan alat.

\section{Metode deteksi LFD (Baumert dan Tran, 2015)}

Lateral Flow Device (LFD) adalah metode immunochemical yang memiliki kesamaan dengan metode tradisional yang sudah mapan yaitu ELISA. Tidak seperti metode tradisional yang melibatkan serangkaian langkah-langkah pencucian serta sejumlah sampel antibodi secara individual, maka lateral flow device menggunakan metode immunochromatographic, penggunaan sampel dan urutan interaksi dengan antibodi dilakukan dalam satu proses yang singkat (Baumert dan Tran, 2015). Sampel yang memiliki kandungan alergen sangat tinggi (umumnya 1.000-10.000 ppm) dapat menimbulkan bias dan kesalahan dalam deteksi menggunakan alat lateral flow device, oleh sebab itu deteksi alergen menggunakan alat lateral flow device ini umumnya digunakan untuk deteksi residu alergen setelah proses pembersihan dan sanitasi dilakukan (Baumert, 2014; Rice dan Lupo, 2014). Pada penelitian ini, pengujian untuk mengetahui residu alergen telur dari peralatan yang telah disanitasi dilakukan dengan metode swab menggunakan alergen test kit lateral flow device Romer Agrastrip $\AA$ Egg. Luas permukaan swab, yaitu $5 \times 5 \mathrm{~cm}$ pada permukaan alat

\section{Validasi dan verifikasi di area produksi (Ryther, 2014)}

Tahapan pengujian di area produksi dilakukan sebagai tahapan proses validasi dan verifikasi. Peralatan produksi adalah peralatan yang digunakan dalam proses pembuatan biskuit kukis yang terdapat di area mixing, cutting, baking dan packing dengan total 10 titik sampling. Menurut Brown dan Arrowsmith (2012), penentuan titik sampling merupakan bagian kritikal dalam pengujian residu alergen. Keseluruhan tahapan proses produksi harus direpresentasikan dalam titik sampling. Pemilihan titik sampling ditentukan berdasarkan tingkat kesulitan proses sanitasi alergen, dan akan lebih baik dipilih di area yang memiliki tingkat kesulitan sanitasi tinggi. Pada penelitian ini, 10 titik sampling tersebut adalah mixer, bak penampung (area mixing), conveyor top (cutting), feeder press roll, die block (area cutting), conveyor cooling 1 (area baking), conveyor MD, starwheel, chute dan stacker besi (area packing). Proses sanitasi diaplikasikan terhadap 2 tipe material peralatan produksi berbahan stainless steel dan polyurethane seperti yang dilakukan dipengujian skala laboratorium. Metode pembersihan secara umum dibagi menjadi dua kategori, yaitu pembersihan kering dan pembersihan basah. Pembersihan basah termasuk di dalamnya CIP (Clean in Process), COP (Cleaning on Place), foaming, peng- 
gunaan gel dan juga pembersihan secara manual. Pembersihan kering termasuk pembersihan menggunakan vakum, menyapu, pengerokan, pengelapan dan penggunaan udara terkompresi (Jackson et al., 2008). Pada percobaan ini digunakan 2 cara pembersihan berdasarkan area produksi, yaitu area mixing dan cutting dengan pembersihan basah/wet cleaning (perendaman peralatan) kecuali untuk top conveyor cutting. Area baking dan packing dengan pembersihan basah terkontrol/controlled wet cleaning (pengelapan basah) terhadap permukaan peralatan.

Kedua proses pembersihan tersebut dilakukan dengan perlakuan pembersihan fisikal terlebih dahulu selama 3 jam, 1 jam, dan 30 menit dengan cara pengerokan dan pengelapan kotoran yang menempel di permukaan alat. Pembersihan fisikal dapat membantu efektivitas proses sanitasi alergen untuk produk yang memiliki kadar air rendah seperti biskuit (Burnett dan Hagbert, 2014). Sebelum proses sanitasi, dilakukan training terhadap karyawan terlebih dahulu untuk meyakinkan proses sanitasi dapat dilakukan secara baik dan konsisten. Pengujian dengan menggunakan metode deteksi ATP dilakukan untuk mengetahui kecukupan dari proses sanitasi dan pengujian dengan alergen test kit lateral flow device dilakukan untuk mengetahui ada tidaknya residu alergen telur. Pengujian terhadap produk yang diproduksi setelah dilakukan proses sanitasi dilakukan sebagai bagian dari tahapan validasi. Pengujian dilakukan di laboratorium eksternal dengan menggunakan metode ELISA (Enzyme-Linked Immunosorbent Assay) dengan LOD 0,31 $\mu \mathrm{g} / \mathrm{g}$ dan LOQ 0,78 $\mu \mathrm{g} / \mathrm{g}$ (Yeung, 2005).

\section{Analisis data}

Analisis data dilakukan pada sampel pengujian sebelum dan setelah proses sanitasi alergen. Komparasi antara data hasil pengujian dengan metode deteksi ATP dan LFD dengan perlakuan pembersihan fisikal/pre-cleaning selama 3 jam, 1 jam, dan 30 menit dilakukan dengan menggunakan microsoft excel 2007.

\section{HASIL DAN PEMBAHASAN}

\section{Tingkat konsentrasi bahan kimia pembersih dan waktu kontak optimum dalam proses sanitasi alergen telur}

Konsentrasi bahan kimia dan waktu kontak optimum dari hasil pengujian di laboratorium dapat dilihat di Tabel 1. Tabel tersebut menunjukkan bahwa semua kombinasi konsentrasi dan waktu kontak terhadap 9 kombinasi pengujian memberikan hasil pengujian negatif residu alergen telur (LOD 2 $\mu \mathrm{g} / 25 \mathrm{~cm}^{2}$ ) menggunakan alat lateral flow device. Hal ini menunjukan bahwa penggunakan bahan kimia pembersih polybrite dengan waktu kontak $(3,5$, dan 8 menit) terbukti efektif dalam membantu menghilangkan residu alergen telur pada permukaan material berbahan stainless steel dan polyurethane. Menurut Jackson (2018) penggunaan bahan kimia pembersih dan waktu kontak berpengaruh dalam proses pembersihan sanitasi alergen. Dijelaskan dalam penelitian Schmidt (2015), bahwa pengotor berbahan dasar protein dan karbohidrat akan dapat dihilangkan secara efektif dengan bahan kimia pembersih berbasis alkali. Penelitian Wang et al. (2010) menunjukan bahwa penggunaan beberapa tahapan proses sanitasi terbukti efektif menurunkan residu alergen. Pada penelitian ini digunakan metode deteksi ATP sebagai indikator umum kebersihan, metode immunoassay untuk deteksi residu alergen.

Pengujian menggunakan metode deteksi ATP menunjukkan bahwa konsentrasi bahan kimia pembersih polybrite terbesar (3\%) dan waktu kontak terlama (8 menit) memberikan nilai hasil RLU (Relative Light Unit) yang terkecil, yaitu 4 RLU. Semakin kecil nilai RLU menunjukan bahwa permukaan alat semakin bersih. Berdasarkan panduan dari metode deteksi ATP 3M Clean Trace ${ }^{\text {TM }}$ Hygiene Monitoring and Management System nilai 150 RLU merupakan batas maksimal kondisi peralatan yang diswab dinyatakan bersih/pass. Jenis material stainless steel memperlihatkan hasil nilai RLU yang lebih baik dibandingkan hasil nilai RLU material polyurethane. Hasil ini menunjukan bahwa material stainless steel lebih mudah disanitasi dibandingkan material polyurethane.

Tabel 1. Hasil pengujian konsentrasi bahan kimia pembersih dan waktu kontak yang optimum dalam sanitasi alergen telur

\begin{tabular}{|c|c|c|c|c|c|c|c|c|}
\hline \multirow{3}{*}{ Tipe Bahan } & \multirow{3}{*}{ Pre- Cleaning } & \multicolumn{7}{|c|}{ Post Cleaning } \\
\hline & & \multicolumn{3}{|c|}{3 Menit (B1) } & \multicolumn{2}{|c|}{5 Menit (B2) } & \multicolumn{2}{|c|}{8 Menit (B3) } \\
\hline & & $\begin{array}{l}\text { Konsentrasi } \\
\text { Bahan Kimia }\end{array}$ & LFD & $\begin{array}{c}\text { ATP } \\
\text { (RLU) }\end{array}$ & LFD & $\begin{array}{c}\text { ATP } \\
\text { (RLU) }\end{array}$ & $\begin{array}{l}\text { LFD } \\
\text { Tes }\end{array}$ & $\begin{array}{l}\text { ATP } \\
\text { (RLU) }\end{array}$ \\
\hline \multirow[t]{3}{*}{ Stainless Steel } & LFD test: & $0,01(\mathrm{~A} 1)$ & $(-)$ & 16 & $(-)$ & 7 & $(-)$ & 5 \\
\hline & Positif & $0,02(\mathrm{~A} 2)$ & $(-)$ & 11 & $(-)$ & 5 & $(-)$ & 5 \\
\hline & ATP: 172 RLU & $0,03(\mathrm{A3})$ & $(-)$ & 8 & $(-)$ & 5 & $(-)$ & 4 \\
\hline \multirow[t]{3}{*}{ Polyurethane } & LFD test: & $0,01(\mathrm{~A} 1)$ & $(-)$ & 28 & $(-)$ & 20 & $(-)$ & 13 \\
\hline & Positif & $0,02(\mathrm{~A} 2)$ & $(-)$ & 11 & $(-)$ & 7 & $(-)$ & 5 \\
\hline & ATP: 169 RLU & 0,03 (A3) & $(-)$ & 6 & $(-)$ & 5 & $(-)$ & 4 \\
\hline
\end{tabular}

Keterangan: ATP= Adenosin Tri Phospate; LFD= Lateral Flow Device; RLU= Relative Light Unit; (-) negatif ; (+) positif 
Menurut Jackson dan Taher (2010), tipe material yang digunakan dalam membuat peralatan industri merupakan salah satu faktor yang berpengaruh dalam proses pembersihan dan sanitasi alergen. Stainless steel merupakan material yang umum dipilih sebagai bahan pembuat peralatan produksi pangan. Hal ini dikarenakan permukaannya yang sangat halus, tahan lama, tahan korosi dan mudah dibersihkan (Gabrić et al., 2016). Jenis material lain yang umum dipilih adalah plastic (PVC, polikarbonat, urethane, vinyl). Permukaan plastik cukup mudah dibersihkan, akan tetapi mudah rusak dengan berjalannya waktu. Kondisi permukaan yang rusak tersebut kemudian menyebabkan peralatan menjadi lebih sulit dibersihkan dan dapat meningkatkan risiko kontaminasi silang (Gabrić et al., 2016). Berdasarkan hasil uji menggunakan alat lateral flow device menunjukan bahwa semua kombinasi perlakuan memberikan hasil yang negatif residu alergen telur, sehingga konsentrasi bahan kimia polybrite yang terkecil (1\%) dan waktu kontak terpendek (3 menit) sudah dianggap dapat menghilangkan residu alergen telur dipermukaan alat. Kombinasi ini selanjutnya diverifikasi di area produksi untuk memvalidasi hasil dari percobaan di laboratorium. Keterbatasan pengujian di laboratorium dengan kemiripan bentuk alat tidak sepenuhnya merefleksikan skala industri menyebabkan tingkat kesulitan dalam proses sanitasi, sehingga tidak dapat diobservasi secara maksimal. Pengujian skala industri diperlukan sebagai langkah validasi dari hasil pengujian di laboratorium.

\section{Hasil validasi efektivitas proses sanitasi alergen telur di area produksi}

Proses validasi dari protokol sanitasi alergen merupakan komponen yang kritikal dalam meyakinkan efektivitas dari proses sanitasi alergen. Menurut Nikoleiski (2015), validasi didefinisikan sebagai proses untuk meyakinkan bahwa prosedur pembersihan yang ada dapat dengan efektif menghilangkan alergen pangan dari peralatan produksi. Proses validasi ini dapat memberikan gambaran kepada industri terkait area-area yang sudah efektif maupun belum efektif dalam proses sanitasi alergen. Umumnya prosedur validasi melibatkan pengecekan terhadap kondisi peralatan dengan cara visual, swab terhadap permukaan alat (ATP, total protein dan spesifik swab alergen), pengujian produk jadi maupun kombinasi dari semua faktor tersebut.

Proses validasi dilakukan di 4 area proses produksi yaitu proses mixing, cutting, oven dan packing. Di empat area proses tersebut kemudian ditentukan titik-titik sampling dalam proses produksi yang mempunyai risiko kontaminasi silang, sehingga kemungkinan residu alergen tertinggal dalam proses sanitasi lebih besar. Sepuluh titik sampling tersebut adalah mixer, bak penampung, conveyor top (cutting), feeder press roll, die block, conveyor cooling 1, conveyor MD, starwheel, chute dan stacker besi. Penentuan titik sampling dan area yang disampling sangat penting dalam mengevaluasi efektivitas dari proses sanitasi. Tujuan dari penentuan titik sampling adalah memaksimumkan kemungkinan deteksi adanya residu alergen pangan di permukaan peralatan dan juga produk non alergen yang dibuat di lini produksi yang sama dengan produk yang mengandung alergen pangan (Brown dan Arrowsmith, 2015).

Tabel 2 menunjukkan hasil pengujian dengan metode deteksi ATP di area produksi dengan perlakuan pembersihan fisikal/pre-cleaning (3 jam, 1 jam, dan 30 menit), bahan kimia pembersih polybrite $1 \%$ dan waktu kontak 3 menit. Proses pembersihan fisikal/pre-cleaning dengan cara pengerokan dan pengelapan peralatan produksi sampai bersih dari sisa adonan dan produk. Proses sanitasi dilanjutkan dengan pembersihan menggunakan bahan kimia pembersih polybrite dengan konsentrasi $1 \%$ dan waktu kontak selama 3 menit yang merupakan kombinasi yang optimum berdasarkan hasil percobaan di laboratorium.

Data menunjukkan bahwa semakin lama pembersihan fisikal/pre-cleaning dilakukan, nilai RLU (Relative Light Unit) yang dihasilkan semakin kecil kecuali untuk alat feeder press roll. Hasil pengujian setelah pembersihan menggunakan bahan kimia pembersih polybrite $1 \%$ dan 3 menit, didapatkan angka RLU dari metode deteksi ATP menunjukkan angka di bawah 100 RLU untuk semua titik sampling (kecuali bak penampung). Proses sanitasi dengan pembersihan fisikal 30 menit dilanjutkan dengan bahan kimia pembersih polybrite 1\%, 3 menit, menunjukan angka RLU yang semakin besar. Standar nilai RLU yang digunakan untuk metode deteksi ATP menggunakan 3M Clean Trace ${ }^{T M}$ Luminometer adalah 1) Nilai RLU kurang dari 150 merupakan indikasi peralatan bersih (pass/green); 2) Nilai RLU antara 150-299 merupakan indikasi peralatan memerlukan perhatian untuk dibersikan kembali (caution/ yellow); dan 3) Nilai RLU di atas 300 merupakan indikasi peralatan masih kotor (fail/red). Berdasarkan panduan tersebut, pengurangan waktu pembersihan fisikal/pre-cleaning menjadi kurang dari 30 menit memungkinkan terdapatnya resiko hasil sanitasi tidak akan mencapai hasil yang diharapkan. Hal tersebut terlihat pada Tabel 2, yang menunjukkan hasil pengujian ATP untuk pembersihan fisikal/pre cleaning di area mixing untuk bak penampung dengan proses pembersihan fisikal/pre-cleaning 30 menit nilai ATP yang dihasilkan adalah 119 RLU. Nilai tersebut sudah mendekati ambang nilai 150 RLU yang merupakan indikasi peralatan bersih sesuai dengan panduan yang digunakan. 
Tabel 2. Hasil pengujian dengan metode deteksi ATP

\begin{tabular}{|c|c|c|c|c|c|c|c|c|}
\hline \multirow{3}{*}{ Area } & \multirow{3}{*}{ Tipe Bahan } & \multirow{3}{*}{ Titik Sampling } & \multicolumn{6}{|c|}{ Hasil Pengujian Metode Deteksi ATP (RLU) } \\
\hline & & & \multicolumn{3}{|c|}{ Pre-Clean (jam) } & \multicolumn{3}{|c|}{ Post Clean (jam) } \\
\hline & & & 3 & 1 & 0,5 & 3 & 1 & 0,5 \\
\hline Mixing & Stainless Steel & Mixer & 23 & 141 & 48,782 & 9 & 29 & 70 \\
\hline \multirow{4}{*}{ Cutting } & Stainless Steel & Bak Penampung & 38 & 105 & 1,286 & 7 & 39 & 119 \\
\hline & Polyurethane & Conveyor top (cutting) & 32 & 40 & 114 & 11 & 13 & 25 \\
\hline & Stainless Steel & Feeder press roll & 59 & 50 & 34 & 16 & 14 & 12 \\
\hline & Polyurethane & Die block & 20 & 36 & 358 & 14 & 13 & 7 \\
\hline Baking & Polyurethane & Conveyor cooling 1 & 20 & 28 & 57 & 4 & 13 & 17 \\
\hline \multirow[t]{4}{*}{ Packing } & Polyurethane & Conveyor MD & 85 & 88 & 1,296 & 5 & 14 & 13 \\
\hline & Stainless Steel & Starwheel & 41 & 49 & 97 & 12 & 37 & 55 \\
\hline & Stainless Steel & Chute & 126 & 137 & 812 & 12 & 33 & 67 \\
\hline & Stainless Steel & Stacker besi & 82 & 94 & 858 & 11 & 13 & 55 \\
\hline
\end{tabular}

Keterangan: ATP $=$ Adenosin Triphospate

Penelitian Moerman dan Mager (2016) menunjukkan metode pembersihan fisikal dengan cara pengerokan dan pengelapan dapat menghilangkan kotoran yang menempel secara kuat dengan optimal. Penelitian ini proses pembersihan fisikal yang dilakukan adalah dengan metode scrapping atau pengerokan manual. Pembersihan fisikal secara manual diperlukan untuk menghilangkan pengotor di permukaan peralatan industri, lamanya waktu pembersihan dapat dikurangi dengan penggunaan bahan kimia dengan konsentrasi yang tepat (Ryther, 2014) Hal ini juga dijelaskan Allen dan Wang (2014) bahwa pembersihan pengotor secara manual diperlukan sebelum pembersihan mengunakan bahan kimia pembersih untuk mendapatkan hasil pembersihan yang optimal.

Tujuan proses sanitasi secara keseluruhan adalah meyakinkan bahwa peralatan produksi dapat dibersihkan dan residu alergen dapat dihilangkan. Pengujian menggunakan metode deteksi ATP dalam penelitian digunakan untuk memahami kecukupan dari proses dan prosedur sanitasi alergen yang dilakukan. Berdasarkan penelitian Jackson and Taher (2010), tidak terdapat korelasi antara hasil pengujian menggunakan metode deteksi ATP dan metode deteksi spesifik alergen LFD, sehingga diperlukan pengujian menggunakan metode deteksi spesifik alergen yang dalam penelitian ini digunakan metode deteksi LFD.

Tabel 3 menunjukkan hasil pengujian dengan metode deteksi LFD di area produksi dengan perlakuan pembersihan fisikal/pre-cleaning ( $3 \mathrm{jam}, 1 \mathrm{jam}$, dan 30 menit), bahan kimia pembersih polybrite $1 \%$ dan waktu kontak 3 menit. Hasil pengecekan residu alergen telur dengan metode deteksi LFD menunjukkan bahwa dengan konsentrasi bahan kimia polybrite dan waktu kontak yang sama yaitu $1 \%$ dan 3 menit memberikan hasil yang negatif terhadap residu alergen telur di semua titik sampling. Peralatan berbahan stainless steel untuk area packing menunjukkan hasil pengecekan residu telur yang negatif sebelum proses pembersihan dilakukan menggunakan bahan kimia polybrite.
Dijelaskan dalam Bedford et al. (2020) proses sanitasi dalam upaya mengurangi dan menghilangkan residu alergen pangan dapat dilakukan dengan berbagai macam cara, akan tetapi faktor-faktor yang memengaruhi proses ini umumnya sama. Faktorfaktor tersebut diantaranya tipe bahan alergen yang dibersihkan (bubuk, pasta, mengandung kandungan lemak tinggi, dan lain lain), jumlah alergen pangan yang bersentuhan dengan permukaan peralatan proses, tipe material dari peralatan proses dan karakteristik dari permukaan peralatan proses yang kontak dengan bahan alergen pangan (halus, bertekstur atau berpori). Karakteristik dari produk yang dihasilkan di area packing adalah biskuit kukis yang bersifat memiliki kadar air yang rendah (kurang dari $5 \%)$ atau kering. Proses sanitasi untuk produk kering umumnya lebih mudah dilakukan karena produk umumnya tidak menempel erat pada permukaan peralatan (Nikoleiski, 2015). Selain itu, penggunaan material stainless steel banyak ditemukan di industri makanan karena memenuhi kriteria spesifik terkait hygienic design seperti tidak korosi ketika kontak dengan makanan ataupun bahan kimia pembersih, mudah dibersihkan, tidak bersifat tosik, berbau, ataupun menyerap bahan, serta tahan terhadap abrasi, retak, dan pengelupasan (Nikoleiski, 2015; Jackson, 2018).

Gambar 1 menunjukkan perbandingan antara hasil pengujian dengan metode deteksi ATP dan metode deteksi LFD setelah proses pembersihan fisikal/pre-cleaning (3 jam, 1 jam, dan 30 menit) dan setelah proses sanitasi alergen menggunakan bahan kimia pembersih polybrite $1 \%$, waktu kontak 3 menit. Area yang ditunjukan adalah area mixing dan cutting yang didapatkan hasil bahwa semakin berkurang waktu pembersihan fisikal/pre-cleaning, maka hasil pengujian dengan metode deteksi ATP memperlihatkan nilai RLU yang semakin besar. Didapatkan hasil yang konsisten terhadap peralatan berbahan stainless steel di area packing, hasil pengecekan residu telur yang negatif sebelum proses pembersihan ditunjukkan oleh Gambar 2. 
Tabel 3. Hasil pengujian dengan metode deteksi LFD

\begin{tabular}{|c|c|c|c|c|c|c|c|c|}
\hline \multirow{3}{*}{ Area } & \multirow{3}{*}{ Tipe Bahan } & \multirow{3}{*}{ Titik Sampling } & \multicolumn{6}{|c|}{ Hasil Pengujian Metode Deteksi LFD } \\
\hline & & & \multicolumn{3}{|c|}{ Pre-Clean (jam) } & \multicolumn{3}{|c|}{ Post Clean (jam) } \\
\hline & & & 3 & 1 & 0,5 & 3 & 1 & 0,5 \\
\hline Mixing & Stainless Steel & Mixer & $(+)$ & $(+)$ & $(+)$ & $(-)$ & $(-)$ & $(-)$ \\
\hline \multirow{4}{*}{ Cutting } & Stainless Steel & Bak Penampung & $(-)$ & $(-)$ & $(+)$ & $(-)$ & $(-)$ & $(-)$ \\
\hline & Polyurethane & Conveyor top (cutting) & $(+)$ & $(+)$ & $(+)$ & $(-)$ & $(-)$ & $(-)$ \\
\hline & Stainless Steel & Feeder press roll & $(+)$ & $(+)$ & $(+)$ & $(-)$ & $(-)$ & $(-)$ \\
\hline & Polyurethane & Die block & $(+)$ & $(+)$ & $(+)$ & $(-)$ & $(-)$ & $(-)$ \\
\hline Baking & Polyurethane & Conveyor cooling 1 & $(-)$ & $(+)$ & $(+)$ & $(-)$ & $(-)$ & $(-)$ \\
\hline \multirow[t]{4}{*}{ Packing } & Polyurethane & Conveyor MD & $(-)$ & $(+)$ & $(+)$ & $(-)$ & $(-)$ & $(-)$ \\
\hline & Stainless Steel & Starwheel & $(-)$ & $(-)$ & $(-)$ & $(-)$ & $(-)$ & $(-)$ \\
\hline & Stainless Steel & Chute & $(-)$ & $(-)$ & $(-)$ & $(-)$ & $(-)$ & $(-)$ \\
\hline & Stainless Steel & Stacker besi & $(-)$ & $(-)$ & $(-)$ & $(-)$ & $(-)$ & $(-)$ \\
\hline
\end{tabular}

Keterangan: LFD= Lateral Flow Device; (-) negatif; (+) posititif

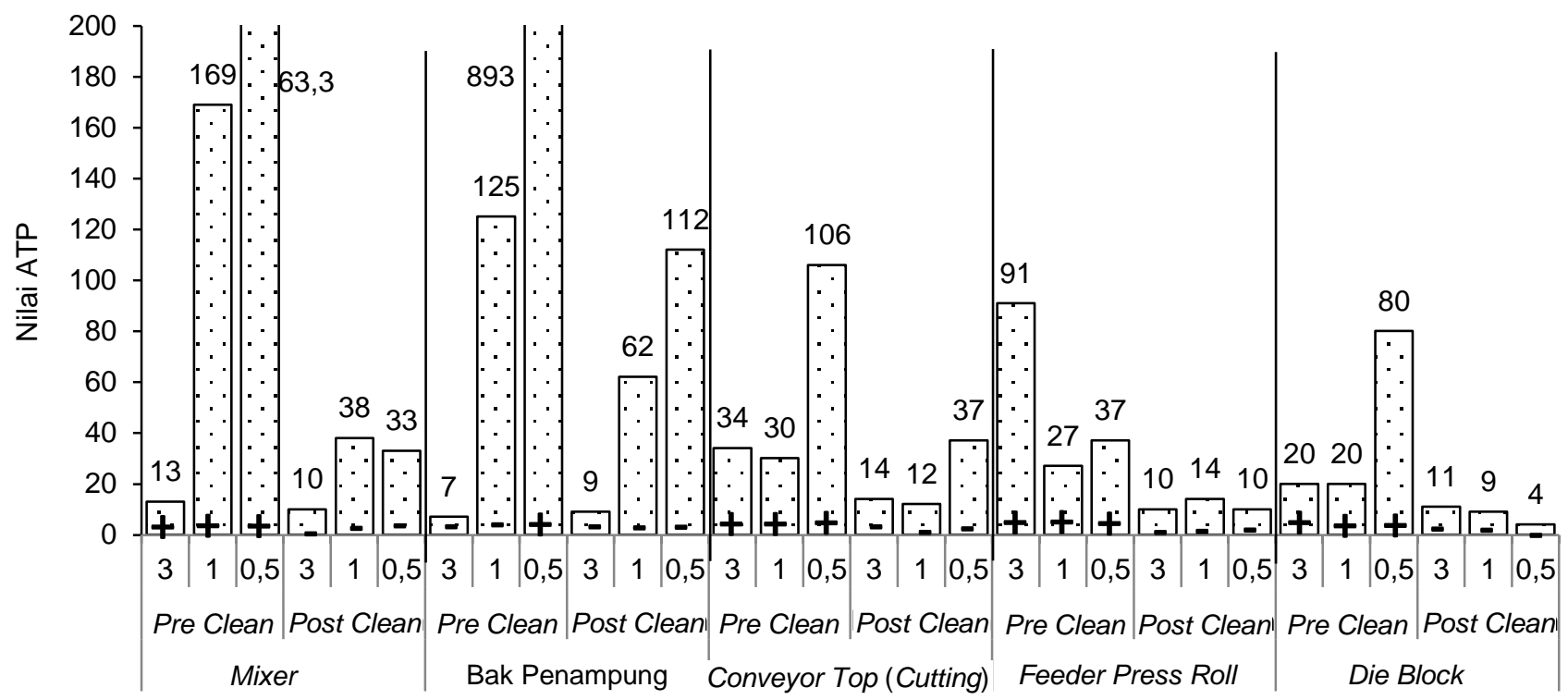

Gambar 1. Perbandingan hasil pengujian metode deteksi ATP dan LFD pada proses sanitasi setelah pembersihan fisikal/pre cleaning ( 3 jam, 1 jam, 30 menit) dan setelah sanitasi menggunakan bahan kimia pembersih polybrite 1\%, 3 menit di area mixing dan cutting

Data ini menunjukan risiko kontaminasi silang dari residu alergen telur di peralatan tersebut sangat rendah, sehingga fokus dan prioritas untuk proses sanitasi dapat dititikberatkan di area proses lain. Produk yang diperoleh dari hasil produksi setelah proses sanitasi alergen dikirimkan ke laboratorium eksternal (laboratorium SGS) untuk dilakukan analisis kuantitatif. Hasil pengujian menunjukan residu alergen telur "tidak terdeteksi" (LOD 0,31 $\mu \mathrm{g} / \mathrm{g}$ dan LOQ $0,78 \mu \mathrm{g} / \mathrm{g}$ ).

\section{Prosedur proses sanitasi alergen dan protokol validasi}

Tahapan selanjutnya setelah proses sanitasi alergen tervalidasi, dan didapatkan prosedur sanitasi alergen yang optimum, keseluruhan dari proses tersebut harus didokumentasikan dengan baik dalam bentuk program sanitasi alergen (Jackson et al., 2008). Patel dan Chotai (2011) menjelaskan bahwa program validasi dikembangkan untuk meyakinkan bahwa terdapat program dokumentasi yang terstruktur untuk dapat mengevaluasi dan mengidentifikasi parameter-parameter kritis yang perlu dikontrol untuk meyakinkan hasil yang dicapai oleh program validasi tersebut.

Berdasarkan penelitian ini didapatkan konsentrasi bahan kimia pembersih, waktu kontak, titik sampling dan waktu pembersihan fisikal/precleaning yang terbukti efektif dalam menghilangkan residu alergen telur dalam proses sanitasi alergen. Didapatkan data terkait tipe bahan dan pengotor yang berdampak dalam proses sanitasi alergen. Keseluruhan dari data tersebut kemudian disusun dalam suatu prosedur sanitasi alergen. Prosedur validasi dan verifikasi termasuk metode deteksi yang dilakukan yaitu metode deteksi ATP dan LFD, kemudian disusun untuk memastikan konsistensi implementasi dari proses sanitasi alergen. Keselu- 
ruhan prosedur ini akan menjadi bagian dari manajemen alergen perusahaan. Tabel 4 menunjukkan prosedur sanitasi alergen pangan yang umumnya terdiri dari 3 bagian penting: Standar Prosedur Operasi Sanitasi (SPOS), prosedur validasi dan prosedur verifikasi dan dokumentasi. SPOS harus berupa prosedur yang sangat rinci yang di dalamnya mencakup: 1) deskripsi area proses produksi tempat prosedur tersebut diimplementasikan, untuk produksi biskuit, area proses produksi meliputi area mixing, cutting, oven dan packing, 2) identifikasi yang bertanggung jawab dalam proses sanitasi alergen, dan 3) deskripsi tentang proses sanitasi dilakukan, di dalamnya termasuk setiap tahapan pro- ses sanitasi dan juga konsentrasi bahan kimia pembersih dan waktu kontak yang digunakan.

Patel dan Chotai (2011) menjelaskan bahwa suatu prosedur validasi yang baik harus memiliki dokumentasi yang di dalamnya terdapat informasi dengan jelas terkait area proses validasi yang dilakukan, orang yang melakukan proses tersebut termasuk tanggal dilakukannya, dan juga orang yang melakukan pengecekan atau verifikasi dari pekerjaan yang dilakukan. Pencatatan atau dokumentasi biasanya dilakukan di dalam suatu formulir kontrol yang akan disimpan selama periode waktu tertentu. Hal ini dilakukan untuk kepentingan mampu ditelusur di kemudian hari.

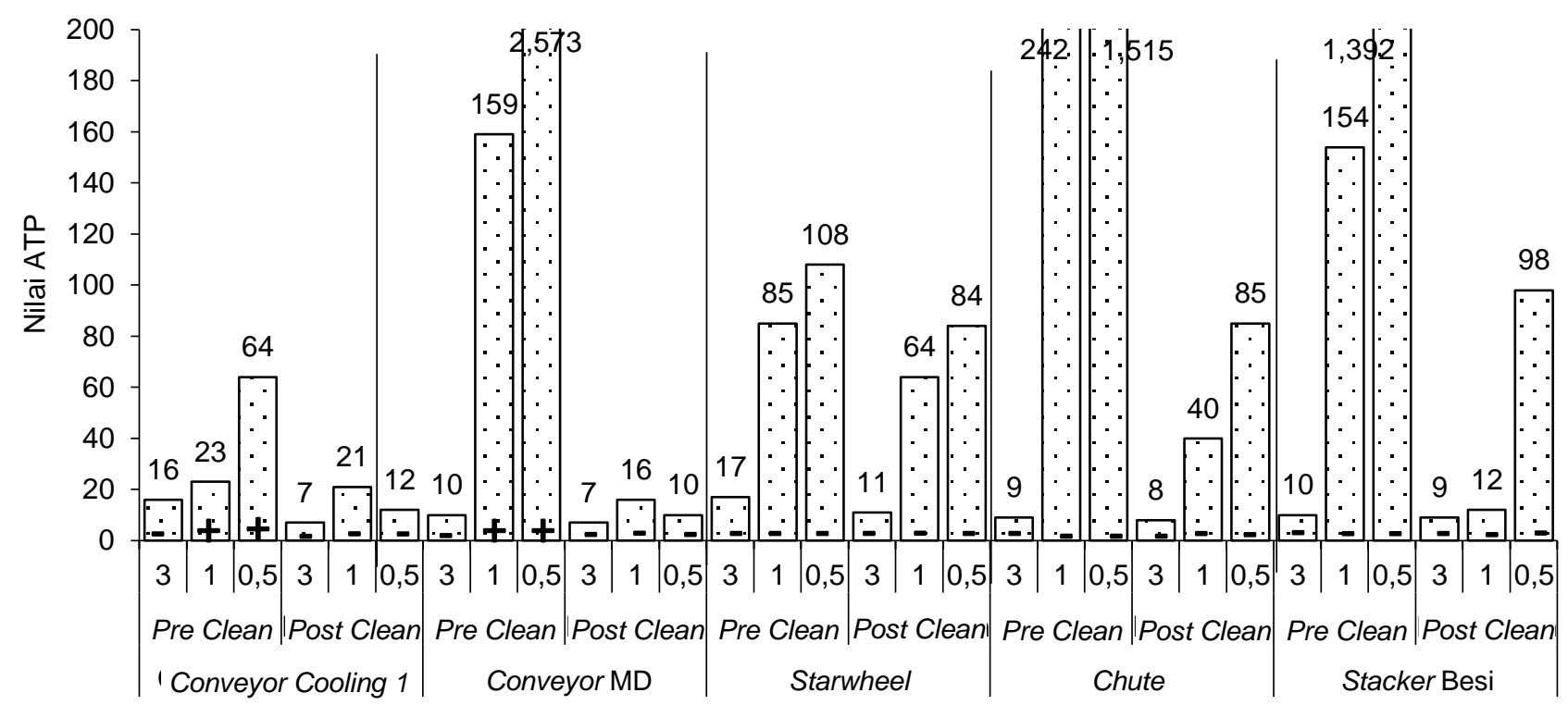

Gambar 2. Perbandingan hasil pengujian metode deteksi ATP dan LFD pada proses sanitasi setelah pembersihan fisikal/pre cleaning ( 3 jam, 1 jam, 30 menit) dan setelah sanitasi menggunakan bahan kimia pembersih polybrite 1\%, 3 menit di area baking dan packing

Tabel 4. Komponen prosedur sanitasi alergen pangan

\begin{tabular}{ll}
\hline \multicolumn{1}{c}{ Komponen Utama } & Detail Prosedur \\
\hline $\begin{array}{l}\text { 1. Standar prosedur } \\
\text { operasi sanitasi }\end{array}$ & a) Prosedur harus jelas dan mudah diikuti \\
& b) Ruang lingkup dari prosedur (peralatan dan area produksi yang akan dibersihkan) \\
& c) Kebutuhan proses sanitasi (peralatan pembersih dan bahan kimia pembersih yang \\
& digunakan, jumlah orang yang diperlukan dalam pelaksaan program, lamanya waktu \\
pelaksanaan) & d) Detail instruksi proses sanitasi \\
\hline 2. Prosedur validasi dan & a) Prosedur harus jelas dan mudah diikuti \\
verifikasi & b) Ruang lingkup dari prosedur validasi dan verifikasi \\
& c) Titik sampling dari berbagai tahapan proses dan peralatan yang dibersihkan \\
& d) Tes analitikal yang digunakan (inspeksi visual, tes ATP dan tes alergen residu) \\
\hline 3. Dokumentasi terkait pelaksanaan sanitasi alergen, proses validasi dan verifikasi \\
\hline 4. Evaluasi secara berkala terhadap Program Sanitasi Alergen \\
\hline 5. Training berkala terhadap karyawan terkait pemahaman mengenai alergen pangan dan Risikonya. Training berkala \\
untuk operator produksi terkait proses sanitasi, validasi dan verifikasi untuk memastikan konsistensi dari hasil \\
\hline
\end{tabular}


Evaluasi secara berkala terhadap program sanitasi alergen dilakukan untuk memastikan konsistensi dan efektivitas dari program. Penelitian ini menghasilkan 4 prosedur sanitasi alergen telur berdasarkan area proses produksi, yaitu area mixing, cutting, oven dan packing. Dihasilkan 2 prosedur validasi menggunakan alat lateral flow device dari Romer (Agrastrip®Egg) dan ATP Biolumiescence dari 3M termasuk tahapan proses validasinya.

\section{KESIMPULAN}

Penggunaan perlakuan pembersihan fisikal/precleaning selama 30 menit, konsentrasi bahan kimia pembersih polybrite $1 \%$ dan waktu kontak 3 menit dalam proses sanitasi terbukti efektif untuk menghilangkan residu alergen telur pada material stainless steel dan polyurethane dalam proses produksi biskuit. Tipe material dan pengotor berpengaruh dalam jumlah residu telur yang menempel di peralatan proses produksi. Area pengemasan (packing) dengan peralatan berbahan stainless steel dan pengotor tipe kering (remahan produk jadi) tidak menunjukkan adanya residu alergen telur sebelum proses sanitasi alergen (residu alergen negatif), sehingga area ini dapat dianggap sebagai area yang tidak kritis dalam proses sanitasi alergen. Dihasilkan 4 prosedur sanitasi alergen telur berdasarkan area proses produksi yaitu area mixing, cutting, baking, dan packing.

\section{DAFTAR PUSTAKA}

Allen KJ, Wang S. 2014. Equipment Cleaning. Encyclopedia of Meat Sciences. 1: 508-514. Academic Press, UK. DOI: 10.1016/B978-0-12384731-7.00212-9.

[AOAC] Association of Official Analytical Chemist. 2019. Performance tested certificate no 041903 $3 \mathrm{M}$ Clean-trance hygiene monitoring and management system. AOAC Inc, Arlington, US.

Baumert JL. 2014. Detecting and Measuring Allergens in Food. In Risk Management for Food Allergy, ed. CB Madsen, RW Crevel, C Mills, and SL Taylor SL. 215-225. Elsevier Inc, Oxford, UK. DOI: 10.1016/B978-0-12-381988-8. 00013-0.

Baumert JL, Tran DH. 2015. 11-Lateral Flow Devices for Detecting Allergens in Food. In Handbook of Food Allergen Detection and Control. Woodhead Publishing Series in Food Science,
Technology and Nutrition. 219-228. Woodhead Publishing, Cambridge, UK. DOI: 10.1533/9781 782420217.2.219.

Bedford B, Liggans G, Williams L, Jackson L. 2020. Allergen removal and transfer with wiping and cleaning methods used in retail and food service. J Food Prot 83: 1248-1260. DOI: 10. 4315/JFP-20-025.

Bedford B, Yu Y, Wang X, Garber EAE, Jackson LS. 2017. A limited survey of dark chocolate bars obtained in the United States for undeclared milk and peanut allergens. J Food Prot 80: 692702. DOI: 10.4315/0362-028X.JFP-16-443.

Brown HM, Arrowsmith HE. 2015. Sampling for Food Allergens. In Handbook for Food Allergen Detection and Control, ed. S. Flanagan. 181197. Woodhead Publishing, Cambridge, UK. DOI: 10.1533/9781782420217.2.181.

Burnett SL, Hagberg R. 2014. Dry Cleaning, Wet Cleaning, and Alternatives to Processing Plant Hygiene and Sanitation. In: Gurtler J, Doyle M, Kornacki J. (eds) The Microbiological Safety of Low Water Activity Foods and Spices. Food Microbiology and Food Safety. Springer, New York. DOI: 10.1007/978-1-4939-2062-4_6.

Caubet J-C, Wang J. 2011. Current understading of food allergy. Pediatr Clin North Am 58: 427443. DOI: 10.1016/j.pcl.2011.02.014.

Cochrane S, Skrypec D. 2014. Food Allergen Risk Management in the Factory-from Ingredients to Products. In Risk Management for Food Allergy, ed. Madsen CB, Crevel RW, Mills C, and Taylor SL. 8: 155-166. Elsevier Inc, Oxford, UK. DOI: 10.1016/B978-0-12-381988-8.00008-7.

[FDA] Food and Drug Administration. 2016. Food allergen labeling and consumer protection act of 2004 (FALCPA). https://www.fda.gov/Food/ GuidanceRegulation/GuidanceDocumentsRegu latorylnformation/Allergens/ucm106187.htm. [2 Agustus 2020].

Gabrić D. Galić K, Timmerman H. 2016. Cleaning of Surfaces. In Handbook of Hygiene Control in the Food industry, ed. Lelieveld $\mathrm{H}$, Holah $\mathrm{J}$, and Gabrić D, 2: 447-463. Woodhead Publishing, Cambridge, UK. DOI: 10.1016/B978-0-08-1001 55-4.00031-5.

Galan-Malo P, Ortiz JC, Carrascon V, Razquin P, Mata L. 2019. A study to reduce the allergen contamination in food-contact surfaces at canteen kitchens. Int J Gastron Food Sci 17: 1- 5. DOI: 10.1016/j.ijgfs.2019.100165. 
Gendell SM, Zhu J. 2013. Analysis of U.S. food and drug administration food alergen recalls after implementation of the food allergen labeling and consumer protection act. J Food Prot 76: 1933-1938. DOI: 10.4315/0362-028X.JFP-13-171.

Gendell S, Zhu J, Nolan N, Gombas K. 2014. Learning from FDA food allergen recalls and reportable foods. Food Safety Magazine. https://www.foodsafetymagazine.com/magazine -archive1/aprilmay-2014/learning-from-fda-foodallergen-recalls-and-reportable-foods/ [28 September 2020].

Holah JT. 2014. Cleaning and disinfection practices in food processing. In Hygiene in Food Processing $\left(2^{\text {nd }}\right.$ ed). 259-304. Woodhead Publishing, Cambridge, UK. DOI: 10.1533/9780857 098634.3.259.

Jackson LS. 2018. Allergen Cleaning: Best Bractices. In Food Allergens. 131-154. Springer International Publishing, Amerika Serikat. DOI: 10.1007/978-3-319-66586-3_8.

Jackson LS, Al-Taher FM. 2010. Efficacy of different dry-cleaning methods for removing allergenic foods from food contact surfaces. Poster presentation, International Association of Food Protection (IAFP) Annual Meeting, Anaheim, CA, August 1-4, 2010.

Jackson LS, Al-Taher FM, Moorman M, DeVries JW, Tippett R, Swanson KMJ, Fu TJ, Salter R, Dunaif G, Estes S, Albillos S, Gendel SM. 2008. Cleaning and other control and validation strategies to prevent allergen cross-contact in food-processing operations. J Food Prot 71: 445-458. DOI: 10.4315/0362-028x-71.2.445.

Jarrad AM. 2019. Firely bioluminescence-based detection of ATP. Australian J Chem 72: 644-645. DOI: 10.1071/ch19127.

Lee AJ, Thalayasingam M, Lee BW. 2013. Food Allergy in Asia: How does it compare. Asia Pac Allergy 3: 3-14. DOI: 10.5415/apallergy.2013.3. 1.3.

Loh W, Tang MLK. 2018. The epidemiology of food allergy in the global context. Int $\mathrm{J}$ Environ Res Public Health 15: 2043. DOI: 10.3390/ijerph150 92043

Moerman F, Mager K. 2016. Cleaning and Disinfection in Dry Food Processing Facilities. In Handbook of Hygiene Control in the Food Industry, ed. Lelieveld H, Holah J, Gabrić D, $\left(2^{\text {nd }}\right.$ ed). 521-554. Woodhead Publishing, Cambridge, UK. DOI: 10.1016/B978-0-08-1001554.00035-2.
Nikoleiski D. 2015. Hygienic design and cleaning as an allergen control measure. In Handbook of Food Allergen Detection and Control. Woodhead Publishing Series in Food Science, Technology and Nutrition. 89-102. Woodhead Publishing, Cambridge, UK. DOI: 10.1533/9781782 420217.1.89.

Ortiz JC, Galan-Malo P, García-Galvez M, Mateos A, Ortiz-Ramos M, Razquin P, Mata L. 2018. Survey on the occurrence of allergens on foodcontact surfaces from school canteen kitchens. Food Cont 84: 449-454. DOI: 10.1016/j.food cont.2017.09.003.

Patel KT, Chotai NP. 2011. Documentation and record: Harmonized GMP requirement. J Young Pharmacists 3: 138-150. DOI: 10.4103/0975-14 83.80303.

Rice JA, Lupo AJ. 2014. Immunodiagnostics in food allergen testing. In Food Allergen Testing: Molecular, Immunochemical and Chromatographic Techniques, ed. Siragakis G, Kizis D. 1328. John Wiley \& Sons, Ltd, Oxford, UK. DOI: 10.1002/9781118519219.ch02.

Ryther R. 2014. Development of a Comprehensive Cleaning and Sanitizing Program for Food Production Facilities. In: Food Safety Management. A Practical Guide for the Food Industry, ed Motarjemi Y, Lelieveld H. 741-768. Academic Press, London, UK. DOI: 10.1016/B978-0-12381504-0.00027-5.

Samady W, Warren C, Wang J, Das R, Gupta R. 2020. Egg allergy in US children. The Journal of allergy and clinical immunology: In Practice 8: 3066-3073. DOI: 10.1016/j.jaip.2020.04.058.

Schmidt RH. 2015. Basic elements of equipment cleaning and sanitizing in food processing and handling operations. University of Coorperative Extension Service, Institute of Food and Agricultural Science. https://edis.ifas.ufl.edu/fs077. [28 September 2020].

Schmidt RH, Erickson DJ, Simms S, Wolfff P. 2010. Characterisctic of food-contact surface material: stainless steel. Food Prot Trends 32: 574-584.

Sicherer S. 2011. Epidemiology of food allergy. J Allergy Clin Immunol 127: 594-602. DOI: 10.10 16/j.jaci.2010.11.044

Soon JM, Brazier AKM, Wallace CA. 2020. Determining common contributory factors in food safety incidents - A review of global outbreaks and recalls 2008-2018. Trends Food Sci Tech 97: 76-87. DOI: 10.1016/j.tifs.2019.12.030. 
Stein K. 2015. Effective alergen management practices to reduce allergens in food. In Handbook of Food Alergen Detection and Control, ed S Glanagal S. 103-132. Woodhead Publishing, UK. DOI: 10.1533/9781782420217.1.103.

Taylor SL, Hefle SL. 2005. Allergen control. Food Sci Technol 59: 40-43, 75.

Wang X, Young OA, Karl DP. 2010. Evaluation of cleaning procedures for allergen control in a food industry environment. J Food Sci 75: 149155. DOI: 10.1111/j.1750-3841.2010.01854.x.
Yeung J. 2005. Enzyme-linked immunosorbent assays (ELISAs) for detectiong allergen in food. In Handbook of Detecting Allergen in Food, ed Hefle SL and Koppelman SJ. 109-124. Woodhead Publishing, UK. DOI: 10.1533/9781845 690557.2.109

Żukiewicz-Sobczak WA, Wŕoblewska P, Adamczuk P, Kopczyński P. 2013. Cause, systoms and prevention of food allergy. Postepy Dermato Alergol 30: 113-116. 